\title{
The Importance of the Tumor Sidedness and Its Relationship with Other Clinicopathological Features in Patients with Colorectal Cancer
}

\author{
Kolorektal Kanserli Hastalarda Tümör Tarafllığının Önemi ve Diğer Klinikopatolojik Özelliklerle lilișkisi
}

\author{
Nilgun Sogutcu', Sahin Lacin², Halis Yerlikaya ${ }^{3}$, Deniz Yilmaz ${ }^{4}$ \\ ${ }^{1}$ Department of Pathology, SBU Gazi Yasargil Training and Research Hospital, Diyarbakir; ${ }^{2}$ Department of Medical Oncology, Yeditepe \\ University, Faculty of Medicine, Istanbul; ${ }^{3}$ Medical Oncology Clinic, UHS, Gazi Yasargil Training and Research Hospital; ${ }^{4}$ Pathology \\ Department, Dicle University, Diyarbakir, Turkey
}

\section{ABSTRACT}

Aim: Colorectal cancer (CRC) is one of the most common and mortal diseases and prognostic factors have a crucial role in stratifying patients. We aimed to evaluate the importance of CDX2 expression, serum CEA level, and tumor sidedness in CRC patients.

Material and Method: Patients diagnosed with colorectal cancer between September 2014 and December 2019 were included in the study. Serum CEA level, primary tumor bias, CDX2 expression and other demographic characteristics were recorded as variables. All study analyzes were performed using SPSS version 22 statistical software (IBM Corporation).

Results: 152 patients with CRC were included, 64 (42.1\%) of patients were female and $88(57.9 \%)$ of patients were male, the median age of patients was 55 (range 18-93). The median survival of patients with serum CEA level $<3.5 \mathrm{ng} / \mathrm{ml}$, and the patients with CEA level >3.5 ng/m/ was 35.1 and 26.6 months, respectively, and the difference between groups was a statistically significant $(p=0.006)$. There was a positive correlation between disease stage and serum CEA level, metastatic patients had higher serum CEA level than non-metastatic patients $(p=0.009)$. In terms of tissue CDX2 expression, eleven patients (7.2\%) had CDX2 expression negative, 136 (89.5\%) of patients had CDX2 expression positive. The difference between OS rates of patients according to CDX2 expression status was not significant $(p=0.7)$. Despite the longer survival of patients with left-sided than right-sided, the difference was not significant, the median OS was 67.6 and 29.7 months, respectively ( $p=0.3$ ). The median follow-up time was 24.1 months.

Conclusion: The serum CEA level was found as a clear prognostic factor for CRC patients. Additionally, CDX2 expression positive and left-sided primary tumors had longer survival as reported in the literature. Also, our patient stratification model based on tumor sidedness and serum CEA level obtained promising outcomes but need to be confirmed by larger and prospective trials.

Key words: CDX2; CEA; colorectal cancer; serum, sidedness

\section{ÖZET}

Amaç: Kolorektal kanser (KRK) en yaygın ve ölümcül hastalıklardan biridir ve hastaların sınıflandırılmasında prognostik faktörler çok önemlidir. Bu çalıșmada, KRK hastalarında CDX2 ekspresyonu, serum CEA düzeyi ve tümör tarafılığının önemini değerlendirmeyi amaçladık.

Materyal ve Metot: Eylül 2014-Aralık 2019 tarihleri arasında hastalık evresine bakılmaksızın kolorektal kanser tanısı alan hastalar dahil edildi. KRK tanısı primer veya metastatik lezyondan elde edilen patoıjik doku bulguları ile doğrulandı. Serum CEA düzeyi, primer tümör taraflıı̆̆ı (sağ taraf veya sol taraf), CDX2 ekspresyonu ve elde edilen diğer demografik özellikler çalıșma değișkeni olarak kaydedildi. Tüm çalıșma analizleri SPSS sürüm 22 istatistik yazııımı (IBM Corporation) kullanılarak yapıldı.

Bulgular: KRK'li 152 hasta dahil edildi, 64 hasta $(\% 42,1)$ kadın, 88 hasta $(\% 57,9)$ erkek, ortalama yaș 55 (18-93 yaș) idi. Serum CEA düzeyi $<3,5 \mathrm{ng} / \mathrm{ml}$ olan hastalarda ve CEA düzeyi $>3,5 \mathrm{ng} / \mathrm{ml}$ olan hastalarda ortalama sağkalım sırasıyla 35,1 ve 26,6 aydı ve gruplar arasındaki fark istatistiksel olarak anlamlıyd $(p=0,006)$. Hastalık evresi ile serum CEA düzeyi arasında pozitif korelasyon vardı, metastatik hastalarda serum CEA düzeyi metastatik olmayan hastalara göre daha yüksekti $(p=0,009)$. Doku CDX2 ekspresyonu açısından, on bir hastada $(\% 7,2)$ CDX2 ekspresyon negatif, 136 hastada $(\% 89,5)$ CDX2 ekspresyon pozitif bulundu. CDX2 ekspresyon durumuna göre hastaların OS oranları arasındaki fark anlamlı değildi $(p=0,7)$. Sol taraflı hastaların sağ taraflılara göre daha uzun süre hayatta kalmasına rağmen, fark anlamlı değildi, medyan OS sırasıly 67,6 ve 29,7 aydı $(p=0,3)$. Ortalama takip süresi 24,1 aydı.

Sonuç: Serum CEA düzeyi, CRC hastaları için belirgin bir prognostik faktör olarak bulundu. Ek olarak CDX2 ekspresyonu pozitif ve sol taraflı primer tümörlerin literatürde bildirildiği gibi daha uzun sağkalımı vardı. Ayrıca, tümör taraflıı̆ı ve serum CEA düzeyine dayanan hasta sınıflama modelimiz umut verici sonuçlar elde etmiștir, ancak daha büyük ve prospektif çalıșmalarla doğrulanması gerekmektedir.

Anahtar kelimeler: CDX2; CEA; kolorektal kanser; serum; tümör gelișim tarafı

IIetișim/Contact: Nilgun Sogutcu, SBU Gazi Yasargil Training and Research Hospital, Department of Pathology, Diyarbakir, Turkey • Tel:05053978421 • E-mail: nilgunsogutcu@gmail.com • Geliș/Received: 19.06.2020 • Kabul/Accepted: 13.10.2020

ORCID: Nilgün Söğ̈̈tçü, 0000-0002-2455-2964 • Şahin Laçin, 0000-0002-8770-9842 • Halis Yerlikaya, 0000-0003-4300-9972 • Deniz Yulmaz, 0000-0003-3934-5914 


\section{Introduction}

Colorectal cancer (CRC) is one of the most common and mortal diseases. According to the World Health Organization GLOBOCAN database, CRC is the third most commonly diagnosed cancer in males and the second in females, and the incidence of the disease is higher in males than in females ${ }^{1}$. There are diverse subtypes of colorectal tumors such as carcinomas, neuroendocrine neoplasms, hamartomas, mesenchymal tumors, lymphomas. Among carcinomas, more than 90 percent are adenocarcinomas, however, other histologic types such as neuroendocrine neoplasms, hamartomas, mesenchymal tumors, lymphomas are relatively uncommon ${ }^{2}$. Adenocarcinoma is classified according to its histological differentiation, and some of these histologic variants carry prognostic significance. In this context, signet ring, poorly differentiated, or undifferentiated carcinomas are aggressive adenocarcinoma subtypes with a poor prognosis $^{3-5}$. Immunohistochemistry (IHC) evaluation of tumor tissue is done routinely by pathologists and generally used to provide clues to the origin. Among these evaluations, cytokeratin 7 (CK7) and CK20 are used routinely to evaluate metastatic adenocarcinoma of the unknown primary site ${ }^{6-8}$. CK20 and CK7 are particularly used for the differentiated diagnosis of a primary colorectal malignancy from mucinous ovarian cancer?. In addition to IHC for CK20 and CK7, especially for the colorectal origin, caudal type homeobox transcription factor 2 (CDX2) is commonly used as a highly specific tissue biomarker for well-differentiated intestinal epithelium. Therefore, there is a correlation between lack of CDX2 expression and poorly differentiated adenocarcinoma. The tumor tissues of around $7 \%-13 \%$ of CRC cases don't express CDX2 and these patients have a worse prognosis ${ }^{10}$. Besides the aforementioned parameters like pathologic stage, the histologic grade of differentiation, and CDX2, serum level of serum carcinoembryonic antigen (CEA) is a prognostic parameter in CRC. Elevated serum CEA levels have an adverse impact on survival that is independent of tumor stage $^{11,12}$. The investigations regarding prognostic factors for patients with colorectal cancer are ongoing and a dynamic field. Recently accumulated data suggest that the primary tumor site may be prognostic and predictive of the benefit from the therapies ${ }^{13}$. Because primary tumors that originate from the left and right sides of the colon have different clinical and molecular features ${ }^{14}$. However, the particular essential functions of the left and right sides in the colon are not completely understood and the researches that try to define the meaning of sidedness are continuing ${ }^{15}$. The aim of our study is to evaluate the importance of CDX2 expression, serum CEA level, and tumor sidedness in CRC patients and to examine their prognostic values.

\section{Material and Method}

\section{Patients}

The patients who diagnosed with colorectal cancer regardless of disease stage between September 2014 and December 2019 were included. The diagnosis of CRC was confirmed with pathological tissue findings obtained from the primary or metastatic lesion. The inclusion criteria were patients who had a diagnosis of CRC based on histopathological or cytological findings, with any stage of the disease, any level of serum CEA concentrations, adequate hematological and biochemical parameters, and patients aged 18 years or older. Patients were excluded if they had a different diagnosis other than CRC. Patient stages were evaluated according to the TNM staging system. Patients' stages classified as metastatic and non-metastatic due to the unbalanced distribution of patients according to disease stages. The patients' treatment options had been discussed in our interdisciplinary tumor boards and the treatment options have been suggested based on the most commonly used guidelines. The conducted treatment options like systemic cytotoxic treatment with/without biologic agents, a tyrosine kinase inhibitor, and best supportive care (BSC) were determined as study variables. Biologic agents that applied with systemic cytotoxic chemotherapy in the study were epidermal growth factor receptor inhibitors (anti-EGFR) (panitumumab or cetuximab), and vascular endothelial growth factor inhibitors (antiVEGF) (bevacizumab, aflibercept, and ramucirumab). Additionally, regorafenib as sole tyrosine kinase inhibitor had been used in beyond second-line treatment of the disease. The survival of the patients was calculated according to all variable that determined for the study like serum CEA level, primary tumor sidedness (right side or left side), gender, CDX2 expression, tumor differentiation, recurrence status, and metastatic site (lung, liver, peritoneum, and others). The distal third of the transverse was adopted as the landmark for distinguishing right-sided vs. left-sided cancers because this location is known as the point that separating the midgut from the hindgut ${ }^{16}$. We created prognostic groups with serum CEA levels and tumor sidedness and tried to better estimate of the patients' survival. Prognostic group 1 was composed of patients with right-sided primary tumor 
and CEA level $\geq 3.5 \mathrm{ng} / \mathrm{ml}$ and prognostic group 2 was composed of patients with left-sided primary tumor and serum CEA levels $<3.5 \mathrm{ng} / \mathrm{ml}$.

\section{Ethical Approval}

Our study was designed and conducted according to the Helsinki declaration. The study approval was obtained from the Ethics Committee of the hospital.

\section{Statistical Analysis}

The overall survival (OS) was defined as the time from diagnosis date to death or censorship; patients whose follow-up were lost, they censored at the date they were last known to be alive. OS for all patients calculated, and the effects of the determined variable on survival were calculated. Survival rates were estimated by the Kaplan-Meier method, and the log-rank test was used to compare OS rates between groups. The patient characteristics and differences were compared between those receiving different treatment options for CRC. Categorical variables, number of patients and percentage of patients in each category were provided, and ChiSquare test $\left(\mathrm{X}^{2}\right)$ or Fisher's exact test was used to test for statistical differences between the determined groups. The Cox proportional hazards model was used for univariable and multivariable associations between survival and the covariates. Hazard ratios (HRs) with $95 \%$ confidence intervals (CIs) were calculated. All tests were 2 -sided with a significance level of 0.05 . Analyses were performed using SPSS version 22 statistical software (IBM Corporation, Somers, New York, USA).

\section{Results}

152 patients with CRC were determined who were treated or followed up at our hospital. Sixty-four (42.1\%) of patients were female and 88 (57.9\%) of patients were male, the median age of 152 patients was 55 (range 1893). The demographic and clinical characteristics of the patients at baseline are listed in Table 1. The disease stage of the patients according to the TNM staging system, in a total of 110 patients, there were $69(45.4 \%)$ CRC patients classified as non-metastatic, 39 (25.7\%) of patients classified as the metastatic stage, and 44 (28.9\%) of patients were not able to be classified. There was a statistically significant difference between the median overall survival of metastatic CRC patients according to the subtype of chemotherapy and biologic agent which were FOLFOX plus biologic agent and FOLFIRI plus biologic agent, 33.6 months for patients treated with
FOLFOX plus biologic agent, 13.4 months for patients treated with FOLFIRI plus biologic agent $(\mathrm{p}<0.001)$ (Figure 1). The patients were divided into two groups according to their serum CEA level, the first group was included the patients with serum CEA level $<3.5 \mathrm{ng} / \mathrm{ml}$, and the second group was included the patients with CEA level $>3.5 \mathrm{ng} / \mathrm{ml}$. There was a statistically significant difference between the median OS rates of the first and the second groups, mOS rate was 35.1 and 26.6 months, respectively $(\mathrm{p}=0.006)$ (Figure 2$)$. There was a positive correlation between disease stage and serum

Table 1. Baseline demographic and clinical characteristics of the patients

\begin{tabular}{|c|c|c|c|}
\hline \multicolumn{3}{|c|}{ Characteristics of the patients } & \multirow{2}{*}{$\begin{array}{c}\text { Percentage } \\
100 \%\end{array}$} \\
\hline Total patients & & 152 & \\
\hline \multicolumn{2}{|c|}{ Median age of all patients } & 55 (18-93) & $100 \%$ \\
\hline \multirow[t]{2}{*}{ Median age } & Female & $52(19-93)$ & $42.1 \%$ \\
\hline & Male & 57 (18-90) & $57.9 \%$ \\
\hline \multirow[t]{2}{*}{ Gender } & Female & 64 & $42.1 \%$ \\
\hline & Male & 88 & $57.9 \%$ \\
\hline \multirow{3}{*}{$\begin{array}{l}\text { Tumor CDX2 } \\
\text { status }\end{array}$} & Positive & 136 & $89.5 \%$ \\
\hline & Negative & 11 & $7.2 \%$ \\
\hline & Not reported & 5 & $3.3 \%$ \\
\hline \multirow{3}{*}{$\begin{array}{l}\text { Prognostic } \\
\text { groups }\end{array}$} & Group 1 & 32 & $21.1 \%$ \\
\hline & Group 2 & 13 & $8.6 \%$ \\
\hline & Not reported & 107 & $70.3 \%$ \\
\hline \multirow{3}{*}{$\begin{array}{l}\text { Tumor } \\
\text { sidedness }\end{array}$} & Left & 86 & $56.6 \%$ \\
\hline & Right & 39 & $25.7 \%$ \\
\hline & Not reported & 27 & $17.7 \%$ \\
\hline \multirow{5}{*}{$\begin{array}{l}\text { Patient's } \\
\text { blood type }\end{array}$} & A & 43 & $28.3 \%$ \\
\hline & B & 14 & $9.2 \%$ \\
\hline & $A B$ & 6 & $3.9 \%$ \\
\hline & 0 & 44 & $28.9 \%$ \\
\hline & Not reported & 45 & $29.7 \%$ \\
\hline \multirow{3}{*}{$\begin{array}{l}\text { Disease } \\
\text { stage }\end{array}$} & Non-metastatic & 69 & $45.4 \%$ \\
\hline & Metastatic & 39 & $25.7 \%$ \\
\hline & Not reported & 44 & $28.9 \%$ \\
\hline \multirow{8}{*}{$\begin{array}{l}\text { The first-line } \\
\text { treatment }\end{array}$} & FUFA & 2 & $1.3 \%$ \\
\hline & Capecitabine & 21 & $13.8 \%$ \\
\hline & FOLFOX & 21 & $13.8 \%$ \\
\hline & CAPOX & 18 & $11.8 \%$ \\
\hline & FOLFOX plus biologic agent & 17 & $11.2 \%$ \\
\hline & FOLFIRI plus biologic agent & 20 & $13.2 \%$ \\
\hline & Chemoradiotherapy & 6 & $3.9 \%$ \\
\hline & Not reported & 47 & $31 \%$ \\
\hline
\end{tabular}




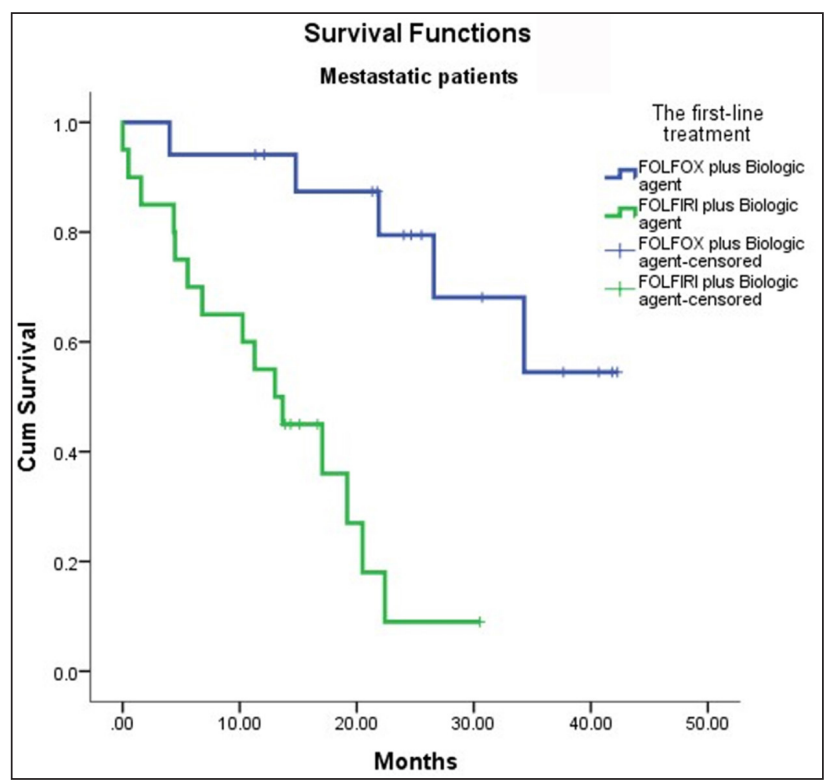

Figure 1. Survival analysis of metastatic patients according to FOLFOX or FOLFIRI with biologic agent.

CEA level, metastatic patients had higher serum CEA level than non-metastatic patients $(\mathrm{p}=0.009)$. The mean serum CEA level in non-metastatic and metastatic patients was $10.3 \mathrm{ng} / \mathrm{ml}$ and $227.8 \mathrm{ng} / \mathrm{ml}$, respectively. In tumor tissue, eleven patients (7.2\%) had CDX2 expression negative, 136 (89.5\%) of patients had CDX2 expression positive and 5 patients weren't reported. The difference between OS rates of patients with CDX2 expression negative and positive was not significant, the median OS rate was 28.5 and 58.8 months, respectively $(\mathrm{p}=0.7)$ (Figure 3). Tumor sidedness in patients regardless of disease stage, despite longer survival of patients with left-sided than right-sided, the difference was not significant, the median OS was 67.6 and 29.7 months, respectively $(\mathrm{p}=0.3)$ (Figure 4$)$. We combined serum CEA level with tumor sidedness to better estimate of the patients' survival, and the survival of patients with left-sided tumor and serum CEA level $<3.5 \mathrm{ng} / \mathrm{ml}$ as prognostic group 1 was significantly longer than patient with right-sided and serum CEA level $\geq 3.5 \mathrm{ng} / \mathrm{ml}$ as prognostic group $2(\mathrm{p}=0.012)$ (Figure 5$)$. The potential factors determined with univariate analyses were further entered into the Cox regression analysis which were patient's gender, serum CEA level, tumor sidedness, tumor differentiation, IHC CDX2 expression, recurrent status, prognostic groups, and tumor metastatic involvement side (Table 2). We found three factors that statistically significantly had effects on the overall survival of

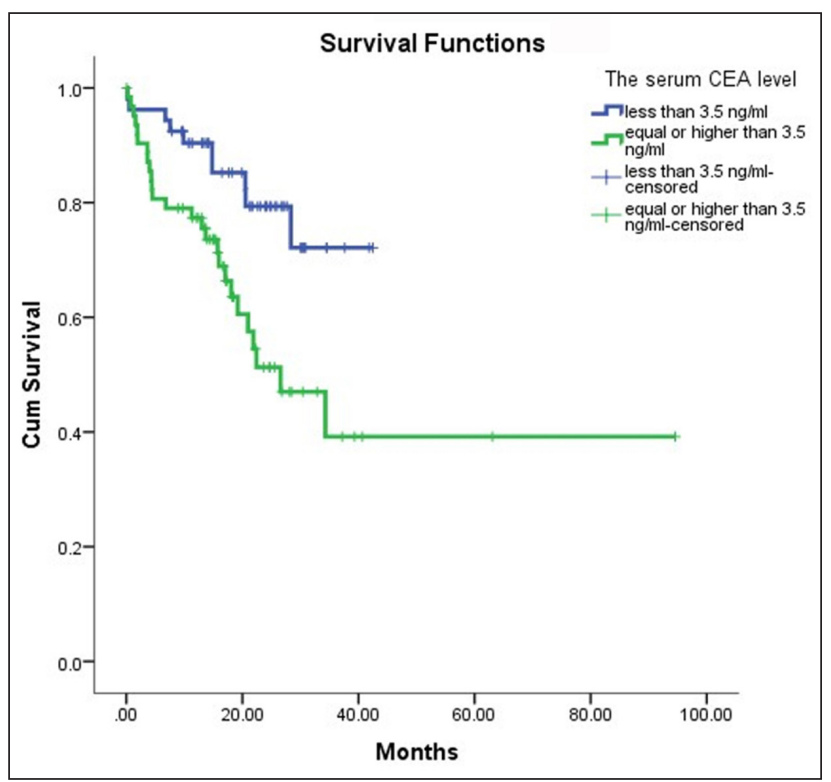

Figure 2. Patients' survival curve according to the serum CEA level.

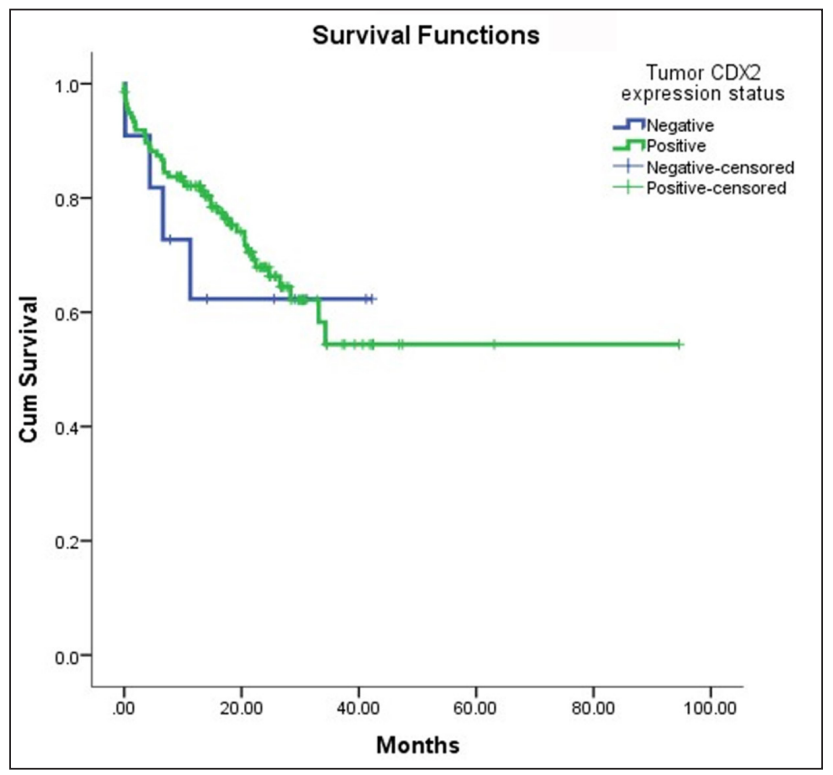

Figure 3. The survival curve according to tumor tissue CDX2 status.

the patients. These factors were serum CEA level, prognostic group, and the disease recurrent status. The higher serum CEA level, prognostic group 2 which includes patients with right-sided primary and serum CEA level $\geq 3.5 \mathrm{ng} / \mathrm{ml}$, and positive recurrence status increased the mortality rate in the patients. Nevertheless, we could no found a significant effect of gender, tumor sidedness, tumor differentiation, IHC CDX2 expression and tumor metastatic involvement side on survival. The median time of follow-up was 24.1 months. 


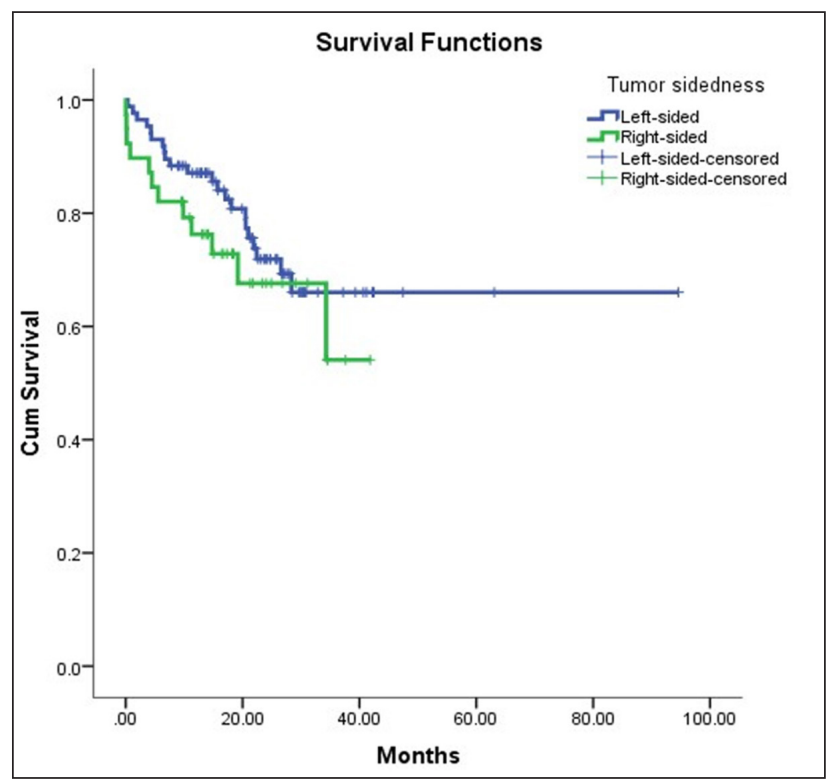

Figure 4. Kaplan-Meier survival curve according to tumor sidedness.

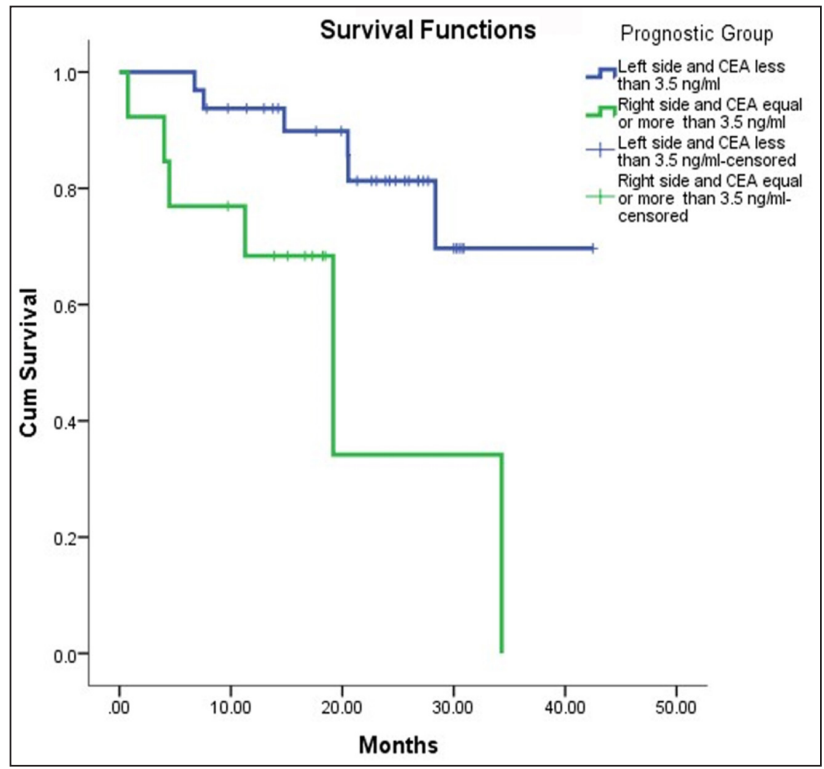

Figure 5. Kaplan-Meier prognostic groups' survival curve.

\section{Discussion}

In colon cancer, prognostic factors play a crucial role in patients' risk stratification and treatment options recommendation. In this context, several features which include tumor stage, tumor grade, microsatellite instability (MSI), lymphovascular and perineural invasion, molecular characteristics (KRAS, NRAS, BRAF, and HER2), primary tumor sidedness have been used for stratification and treatment algorithms in colon cancer patients. In our study, we revealed the effects of various
Table 2. The Cox regression analysis of the factors and their effects on survival

\begin{tabular}{|c|c|c|}
\hline Parameters & Hazard ratio $(95 \% \mathrm{Cl}) ¥$ & $P$ value \\
\hline $\begin{array}{l}\text { Serum CEA level } \\
>3.5 \mathrm{ng} / \mathrm{ml} \text { vs. }<3.5 \mathrm{ng} / \mathrm{ml}\end{array}$ & $2.69(1.29-5.59)$ & $0.008^{*}$ \\
\hline Right side vs. left side & $1.44(0.71-2.92)$ & 0.3 \\
\hline $\begin{array}{l}\text { Metastatic stage vs. } \\
\text { non-metastatic stage }\end{array}$ & $4.03(2.08-8.88)$ & $<0.001^{*}$ \\
\hline $\begin{array}{l}\text { Prognostic group } 2 \text { vs. } \\
\text { prognostic group } 1\end{array}$ & $4.36(1.28-14.85)$ & $0.02^{*}$ \\
\hline Male vs. female & $1.18(0.66-2.10)$ & 0.6 \\
\hline $\begin{array}{l}\text { IHC CDX2 status } \\
\text { negative vs. positive }\end{array}$ & $1.17(0.42-3.27)$ & 0.7 \\
\hline Modarate diff. vs. Well diff. & $1.83(0.51-6.55)$ & 0.3 \\
\hline Poor diff. vs. Well diff. & $2.73(0.61-12.30)$ & 0.2 \\
\hline Recurrent vs. non-recurrent & $6.01(2.56-14.10)$ & $<0.001^{*}$ \\
\hline $\begin{array}{l}\text { Metastatic side, } \\
\text { lung vs. liver }\end{array}$ & $0.62(0.19-2.05)$ & 0.4 \\
\hline $\begin{array}{l}\text { Metastatic side, } \\
\text { peritoneum vs. liver }\end{array}$ & $1.12(0.45-2.82)$ & 0.8 \\
\hline
\end{tabular}

features of CRC patients on the course of the disease by retrospective analysis. These features like serum CEA level, primary tumor sidedness, disease stage, gender, CDX2 expression, recurrence status, and metastatic involvement side. We could not detect the significant prognostic role of CDX2 in our CRC patient population which has been clearly reported in patients with early-stage cancer in the literature. However, serum CEA level was found as a clear prognostic factor in our general patients' population.

As a member of a caudally related homeobox gene family, the CDX2 gene encodes intestine-specific transcription factor (CDX2). Intestinal epithelial cells need the CDX2 for growing and differentiation and it is particularly expressed in the nuclei of intestinal epithelial cells ${ }^{17,18}$. The CDX2 protein expression has been evaluated as a potential prognostic factor in particularly in CRC patients with stage II and III disease. In the trial, CDX2-negative tumors were associated with a lower rate of disease-free survival than CDX2-positive tumors across independent data sets of the study. This association was not confounded by other risk factors that are known to affect survival rates among patients with early-stage colon cancer, such as the primary tumor invasion deepness and the number of lymph nodes resected at the surgery. Additionally, the CDX2 
expression status has been associated with the benefit of chemotherapy in early-stage colon cancer, and negative patients obtained more benefits from chemotherapy than positive patients ${ }^{10}$. However, the role of the CDX2 expression in metastatic CRC remains unclear, because of their poor prognosis, patients with stage IV disease have not been particularly included in the majority of trials. Despite all these inadequacies, the relationship between CDX2 expression and metastatic colon cancer patients has been evaluated in several trials, and the prognostic effect of the expression reported as an independent poor prognostic marker in these patient subgroups as well ${ }^{19}$. We analyzed the prognostic effect of CDX2 in our colorectal cancer patients regardless of the disease stage. In our study, we observed to the median survival of patients with CDX2 expression positive tended to be longer than patients with CDX2 negative as demonstrated previously.

There are increasing shreds of evidence about the prognostic and predictive role of primary tumor sidedness in patients with the metastatic stage of colon cancer. The left and right sides of the colon have distinct clinical and molecular characteristics that have affect tumor behavior ${ }^{13,14,20}$. These distinct clinical and molecular characteristics lead to prognostic and predictive differences. In this context, the relationship between the effectiveness of treatments specifically targeting EGFR and VEGF pathways and the tumors sidedness has been investigated ${ }^{21,22}$. While left-sided RAS wild type (no mutation) tumors are more sensitive to EGFR inhibitors, right-sided tumors do not respond very well, possibly due to the higher frequency of BRAF mutations and other different molecular features ${ }^{23}$. The incidence rate of left-sided CRC is much more common than right-sided, and approximately two-thirds of CRCs are emerging from the left side of the colon ${ }^{24}$. In our study, despite no statistical significance, the patients who had left-sided tumors lived longer than patients with right-sided tumors. In terms of primary tumor location, left-sided tumors were more frequent than right-sided tumors in our patient's population, and this was consistent with the literature. Additionally, notwithstanding the no significant difference between two different chemotherapy regimens, in our metastatic patients, FOLFOX plus the biologic agent was significantly better than FOLFIRI plus biologic agent. However, it is not possible to interpret the superiority of a chemotherapy regimen with this result due to the unbalanced distribution of the tumor sidedness of the patients and the difference of biological agents.
Carcinoembryonic antigen (CEA) is a glycoprotein and member of intracellular adhesion molecules produced in the epithelium of the large intestine to promotes cellular aggregation ${ }^{25,26}$. As a biomarker, CEA has been used for diagnosis, treatment and surveillance in colorectal cancer patients, and elevated serum levels of CEA have been associated with a worse prognosis $^{27,28}$. CEA has been reported to promote aggregation of colon cancer cells and to facilitate tumor metasta$\mathrm{sis}^{29}$. The relationship between elevated baseline CEA and the worse prognosis in patients with metastatic disease has been clearly demonstrated by previous studie $^{30,31}$. In our patient's population, we have clearly reported serum CEA level as a prognostic factor, and patients with lower serum CEA level had significantly longer survival. Additionally, we stratified our patients according to tumor sidedness and serum CEA level, patients with both low serum CEA level and the left-sided tumor had significantly longer survival than patients with right-sided and high serum CEA levels. This stratification may help to better predict the survival of patients with colon cancer but needs to be confirmed by studies with larger and balanced patient distribution.

Our study has several limitations. Firstly, being retrospective makes it difficult to evaluate patients' characteristics effectively and reliably. Secondly, to define the patients to two groups according to the disease stage and not to determine the exact stage's class makes it difficult to obtain accurate information about the survival and prognosis of the patients, so in this sense, it is difficult to make inferences. Thirdly, Classification of all biological agents (anti-EGFR (panitumumab or cetuximab) and anti-VEGF (bevacizumab)) applied to patients in the same group will make insufficient to show the true effectiveness of these agents.

In conclusion, our study evaluated the importance of tumor tissue CDX2 expression, serum CEA level, and tumor sidedness and examined the prognostic values of these factors in our CRC patient population. The serum CEA level was found as a clear prognostic factor for CRC patients. Additionally, despite not statistically significant outcomes, patients with tumor tissue CDX2 expression positive and left-sided primary tumors had longer survival as reported in the literature. Also, our patient stratification model based on tumor sidedness and serum CEA level obtained promising outcomes but need to be confirmed by larger and prospective trials. 


\section{References}

1. Bray F, Ferlay J, Soerjomataram I, Siegel RL, Torre LA, Jemal A. Global cancer statistics 2018: GLOBOCAN estimates of incidence and mortality worldwide for 36 cancers in 185 countries. CA Cancer J Clin 2018;68:394-424.

2. Nagtegaal ID, Odze RD, Klimstra D, Paradis V, Rugge M, Schirmacher P, et al. The 2019 WHO classification of tumours of the digestive system. Histopathology 2020;76:182-188.

3. Secco GB, Fardelli R, Campora E, Lapertosa G, Gentile R, Zoli $S$, et al. Primary mucinous adenocarcinomas and signet-ring cell carcinomas of colon and rectum. Oncology 1994;51:30-4.

4. Hyngstrom JR, Hu CY, Xing Y, You YN, Feig BW, Skibber JM, et al. Clinicopathology and outcomes for mucinous and signet ring colorectal adenocarcinoma: analysis from the National Cancer Data Base. Ann Surg Oncol 2012;19:2814-21.

5. Harrison JC, Dean PJ, el-Zeky F, Vander Zwaag R. From Dukes through Jass: pathological prognostic indicators in rectal cancer. Hum Pathol 1994;25:498-505.

6. Berezowski K, Stastny JF, Kornstein MJ. Cytokeratins 7 and 20 and carcinoembryonic antigen in ovarian and colonic carcinoma. Mod Pathol 1996;9:426-9.

7. Blumenfeld W, Turi GK, Harrison G, Latuszynski D, Zhang C. Utility of cytokeratin 7 and 20 subset analysis as an aid in the identification of primary site of origin of malignancy in cytologic specimens. Diagn Cytopathol 1999;20:63-6.

8. Tot T. Cytokeratins 20 and 7 as biomarkers: usefulness in discriminating primary from metastatic adenocarcinoma. Eur J Cancer 2002;38:758-63.

9. Chu P, Wu E, Weiss LM. Cytokeratin 7 and cytokeratin 20 expression in epithelial neoplasms: a survey of 435 cases. Mod Pathol 2000;13:962-72.

10. Dalerba P, Sahoo D, Paik S, Guo X, Yothers G, Song N, et al. CDX2 as a Prognostic Biomarker in Stage II and Stage III Colon Cancer. N Engl J Med 2016;374:211-22.

11. Harrison LE, Guillem JG, Paty P, Cohen AM. Preoperative carcinoembryonic antigen predicts outcomes in node-negative colon cancer patients: a multivariate analysis of 572 patients. J Am Coll Surg 1997;185:55-9.

12. Thirunavukarasu P, Talati C, Munjal S, Attwood K, Edge SB, Francescutti V. Effect of Incorporation of Pretreatment Serum Carcinoembryonic Antigen Levels Into AJCC Staging for Colon Cancer on 5-Year Survival. JAMA Surg 2015;150:747-755.

13. Hansen IO, Jess P. Possible better long-term survival in left versus right-sided colon cancer - a systematic review. Dan Med J 2012;59:A4444.

14. Richman S, Adlard J. Left and right sided large bowel cancer. BMJ 2002;324:931-2.

15. Hamada H, Meno C, Watanabe D, Saijoh Y. Establishment of vertebrate left-right asymmetry. Nat Rev Genet 2002;3:103-13.

16. Gervaz P, Bucher P, Morel P. Two colons-two cancers: paradigm shift and clinical implications. J Surg Oncol 2004;88:261-6.

17. Olsen J, Espersen ML, Jess P, Kirkeby LT, Troelsen JT. The clinical perspectives of CDX2 expression in colorectal cancer: a qualitative systematic review. Surg Oncol 2014;23:167-76.
18. Verzi MP, Shin H, Ho LL, Liu XS, Shivdasani RA. Essential and redundant functions of caudal family proteins in activating adult intestinal genes. Mol Cell Biol 2011;31:2026-39.

19. Aasebo K, Dragomir A, Sundstrom M, Mezheyeuski A, Edqvist PH, Eide GE, et al. CDX2: A Prognostic Marker in Metastatic Colorectal Cancer Defining a Better BRAF Mutated and a Worse KRAS Mutated Subgroup. Front Oncol 2020;10:8.

20. Missiaglia E, Jacobs B, D’Ario G, Di Narzo AF, Soneson C, Budinska E, et al. Distal and proximal colon cancers differ in terms of molecular, pathological, and clinical features. Ann Oncol 2014;25:1995-2001.

21. Moretto R, Cremolini C, Rossini D, Pietrantonio F, Battaglin F, Mennitto A, et al. Location of Primary Tumor and Benefit From Anti-Epidermal Growth Factor Receptor Monoclonal Antibodies in Patients With RAS and BRAF Wild-Type Metastatic Colorectal Cancer. Oncologist 2016;21:988-94.

22. Venook AP. Metastatic Colorectal Cancer: Lessons Learned, Future Possibilities. J Natl Compr Canc Netw 2016;14:666-8.

23. Lee MS, Menter DG, Kopetz S. Right Versus Left Colon Cancer Biology: Integrating the Consensus Molecular Subtypes. J Natl Compr Canc Netw 2017;15:411-419.

24. Meza R, Jeon J, Renehan AG, Luebeck EG. Colorectal cancer incidence trends in the United States and United kingdom: evidence of right- to left-sided biological gradients with implications for screening. Cancer Res 2010;70:5419-29.

25. Duffy MJ, Lamerz R, Haglund C, Nicolini A, Kalousova M, Holubec L, et al. Tumor markers in colorectal cancer, gastric cancer and gastrointestinal stromal cancers: European group on tumor markers 2014 guidelines update. Int J Cancer 2014;134:2513-22.

26. Beauchemin N, Arabzadeh A. Carcinoembryonic antigen-related cell adhesion molecules (CEACAMs) in cancer progression and metastasis. Cancer Metastasis Rev 201332:643-71.

27. Mitsuyama Y, Shiba H, Haruki K, Fujiwara Y, Furukawa K, Iida $\mathrm{T}$, et al. Carcinoembryonic antigen and carbohydrate antigen 19-9 are prognostic predictors of colorectal cancer with unresectable liver metastasis. Oncol Lett 2012;3:767-771.

28. Strimpakos AS, Cunningham D, Mikropoulos C, Petkar I, Barbachano Y, Chau I. The impact of carcinoembryonic antigen flare in patients with advanced colorectal cancer receiving firstline chemotherapy. Ann Oncol 2010;21:1013-9.

29. Benchimol S, Fuks A, Jothy S, Beauchemin N, Shirota K, Stanners CP. Carcinoembryonic antigen, a human tumor marker, functions as an intercellular adhesion molecule. Cell 1989;57:327-34.

30. Prager GW, Braemswig KH, Martel A, Unseld M, Heinze G, Brodowicz T, et al. Baseline carcinoembryonic antigen (CEA) serum levels predict bevacizumab-based treatment response in metastatic colorectal cancer. Cancer Sci 2014;105:996-1001.

31. Yoshino T, Obermannova R, Bodoky G, Garcia-Carbonero $\mathrm{R}$, Ciuleanu T, Portnoy DC, et al. Baseline carcinoembryonic antigen as a predictive factor of ramucirumab efficacy in RAISE, a second-line metastatic colorectal carcinoma phase III trial. Eur J Cancer 2017;78:61-69. 